$\begin{array}{ll}\text { Abstracta Iranica } & \begin{array}{l}\text { Abstracta Iranica } \\ \text { Revue bibliographique pour le domaine irano-aryen }\end{array} \\ & \text { Volume } \mathbf{2 4} \mid \mathbf{2 0 0 3} \\ & \text { Comptes rendus des publications de } \mathbf{2 0 0 1}\end{array}$

\title{
« Preliminary notes on seven Achaemenid silver objects ». St. Ir. 30, 2, (2001), pp. 163-185.
}

\section{Rémy Boucharlat}

\section{(2) OpenEdition}

Édition électronique

URL : http://journals.openedition.org/abstractairanica/34287

ISSN : 1961-960X

\section{Éditeur :}

CNRS (UMR 7528 Mondes iraniens et indiens), Éditions de l'IFRI

Édition imprimée

Date de publication : 15 mai 2003

ISSN : 0240-8910

\section{Référence électronique}

Rémy Boucharlat, « «Preliminary notes on seven Achaemenid silver objects ». St. Ir. 30, 2, (2001),

pp. 163-185. », Abstracta Iranica [En ligne], Volume 24 | 2003, document 57, mis en ligne le 05 janvier 2010, consulté le 25 septembre 2020. URL : http://journals.openedition.org/abstractairanica/34287

Ce document a été généré automatiquement le 25 septembre 2020.

Tous droits réservés 


\title{
«Preliminary notes on seven
} Achaemenid silver objects ». St. Ir.
30, 2, (2001), pp. 163-185.

\author{
Rémy Boucharlat
}

1 Une étude bien documentée sur cette série d'objets de luxe, mais qui pose un problème de méthode; il est regrettable en effet qu'elle soit donnée avant que des analyses métallurgiques n'aient tenté d'en vérifier l'authenticité. Ces acquisitions du Miho Museum au Japon proviennent du marché des antiquités donc, on peut le supposer, d'un pillage. Dans l'attente de ces analyses, qui ne peuvent pas être concluantes à $100 \%$, l'hypothèse de faux - anciens ou modernes - ne peut être écartée même si, comme le démontre l'A., le poids total des trois phiales de ce lot correspond à 500 sigloi achéménides, ce qui constitue pour elle une garantie d'authenticité. Un faussaire ne pourrait-il pas connaître cette tradition démontrée depuis une douzaine d'années? L'exemple des inscriptions cunéiformes, très probablement fausses, sur les quatre phiales, probablement authentiques mais sans provenance avérée, exportées d'Iran par E. Herzfeld en 1934, est significatif des différents cas à envisager (cf. l'excellent article de A. Gunter et M. C. Root Abs. Ir. 22, nº 133 et ici même N. Sims-Williams, c.r. n 78 ).

\section{INDEX}

Thèmes : 3.2.2. Pré-Achéménides et Achéménides 
AUTEURS

RÉMY BOUCHARLAT

CNRS - Lyon 